\title{
Buddhist Women and Polygamy Issue in Indonesia
}

\section{By: Kustiani}

\section{(Article was presented for the $2^{\text {nd }}$ IABU Conference, 30-3 June 2012, in Thailand)}

\section{Background}

Marriage is a human's phenomenon that commonly practiced since the ancient civilizations regardless geography, religion, race and social classes. Marriage in the Vulgar Latin is marītācum and in the Latin is maritatus, meaning 'to wed, marry and give in marriage'. ${ }^{1}$ Now days, marriage is defined as 1. a formal, usually legally recognized, agreement between a man and a woman making them husband and wife; 2 . a ceremony at which a couple are married. ${ }^{2}$ Marriage of the first meaning is meant in this article and it is not the second one.

There are many kinds of marriage which have been influenced by the religious, social and philosophical viewpoints. Generally, there are three kinds of marriage, namely polygamy, monogamy and group marriage. Monogamy is the practice or custom of being married to only one person at a time. ${ }^{3}$ This is commonly practice in the society and of course this type of marriage can be seen everywhere. But, group marriage is quite rare to be seen. Group marriage involves more than one member of each sex. They live together by sharing husband and wife, and responsibility in taking care of wealth and children. ${ }^{4}$ However, these two types of marriage are not the purpose of this article. The main purpose of this article is to discuss and examine the third type of marriage: polygamy.

The term polygamy is defined in two ways: 1 . the custom of having more than one wife

at the same time $;^{5}$ 2. a marriage where male or female has more than one spouse. ${ }^{6}$ The second definition leads to the other marital terms called polygyny and polyandry. When a female has more than one husband, it is called polyandry; while the male who has many wives is called

\footnotetext{
${ }^{1}$ Ernest Klein. Etymological English Dictionary. London: Elsevier Publishing Company, 1966, p. 941.

${ }^{2}$ Oxford Advanced Learner's Dictionary $5^{\text {th }}$ Edition. Oxford: Oxford University Press, 1995, p. 718.

${ }^{3}$ Oxford Advanced Learner's Dictionary $5^{\text {th }}$ Edition. Oxford: Oxford University Press. 1995, p. 753.

${ }^{4}$ Group Marriage, Encyclopædia Britannica Online, http://www.britannica.com/EBchecked/topic/247131/groupmarriage, retrieved January 28, 2010

${ }^{5}$ Oxford Advanced Learner's Dictionary $5^{\text {th }}$ Edition. Oxford: Oxford University Press. 1995, p. 894.

${ }^{6}$ http://en.wikipedia.org/wiki/Polygamy. Retrieved, 3 October 2011.
} 
polygyny. Polygyny can be found in many places throughout the time whether in the ancient or contemporary time but polyandry is quite rare and difficult to be seen. It might be because of gender issues where in many societies women have less freedom, including freedom to choose and to have many husbands. As far as the historical record is concerned, polyandry has been practiced in Sparta of ancient Greece ${ }^{7}$ and in Hindu society where Draupadi has five husbands (Pandawa) at the same time as depicted in Hindu's epic, Mahābhārata. ${ }^{8}$ In spite of two definitions of polygamy mentioned above, in this analysis, the definition of polygamy is a marriage where a husband has more than one wife. This definition is based on the etymological meaning of polygamy which comes from the Middle France polygamic and from the Late Latin polygamia meaning 'having many wives". 9

Though polygamy is practiced by many Indonesians, it is difficult to show the statistical evidence about how many Indonesian men who are practicing polygamy. It is because many polygamous marriages are usually unregistered to the government. ${ }^{10}$ Likewise, it is also not clear about how many percent of Indonesian Buddhist men are practicing polygamy. Although it is not clear about the percentage, the practice of polygamy takes place among Buddhist and this practice brings to the disadvantage to the Buddhist women such as instigating the domestic violence and neglecting the family's welfare. However, before discussing this problem further, it is better to discuss the practice of polygamy in general first.

\section{Polygamy Practice in Indonesia: From the Ancient to the Present Day}

Polygamy is not the human nature. It is practiced because of many reasons such as social view which considers women as the agent of reproductions, labour and property. Perhaps, because of this reason, polygamy had been practiced since the ancient time ${ }^{11}$ in many societies

\footnotetext{
${ }^{7}$ In the Spartan belief that breeding should be between the most physically fit parents, many older men allowed younger more fit men to impregnate their wives. Other unmarried or childless men might even request another man's wife to bear his children if she had previously been a strong child bearer. For this reason many considered Spartan women polyandrous. http://en.wikipedia.org/wiki/Women_in_Ancient_Sparta. Retrieved $23^{\text {rd }}$ September 2011. Cf. Blundell, Sue (1995), Women in ancient Greece, Cambridge: Harvard University Press, ISBN 9780674954731. Pg. 154

8 J.A.B. Van Buitenen. Mahābhārata. Chicago: University of Chicago Press. 1975, p. 111, p. 138. However Draupadi's husbands have several wives. For example, Arjuna has several wives namely Ulupi, Citrāngadā and Subadra. See: http://id.wikipedia.org/wiki/Arjuna. Retrieved on 11th October 2011.

${ }^{9}$ Ernerst Klein. A Comprehensive Etymological Dictionary of English Language. New York: Elsevier Publishing Company, 1966, p. 1212

${ }^{10} \mathrm{http} / / / \mathrm{www}$.freedom-institute.org/pdf/perempuan_dlm_UU_perkawinan.pdf . Retrieved on $11^{\text {th }}$ October 2011

${ }^{11} \mathrm{Be}$ fruitful and multiply and replenish earth, Genesis I; 28.
} 
including Indonesia. The royal families of Hindu, Buddhist and Islamic kingdoms in Indonesia were not exempted. The practice of polygamy that can be traced back is only those practiced by the royal families because their life story is written in the historical books. Polygamy by royal families usually was because of political reasons such as for the sake of conjoining the power of kingdoms. For example, in order to conjoin the power of Kalingga and Galuh kingdom, there had been marriage between Prince of Galuh, Mandiminyak, with princess of Kalingga, Parwati in the $6^{\text {th }}$ century A.D.. As recorded in the history, Mandiminyak was not only married to Parwati but he also got married to another woman named Pohaci Rahabu. ${ }^{12}$ Polygamy for the sake of strengthening the political relationship of two countries was exemplified by the polygamy of King Brawijaya, king of Majapahit kingdom during $14^{\text {th }}$ century. Besides having several local wives, he had a wife from Campa kingdom known as Putri Dwarawati. Putri Dwarawati was a gift given by General Yan Lu of Ming Dynasty of Campa kingdom to strengthen the relationship between Majapahit and Campa. ${ }^{13}$

In about $15^{\text {th }}$ century A.D., when Islam became prominent religion in the country, polygamy was also practiced by kings of Islamic kingdoms. The most famous king of Mataram Islamic kingdom named Sultan Agung had two chief queens. One was Ratu Kulon, the daughter of leader of Cirebon and the other was Ratu Wetan, Governor Batang's daughter. ${ }^{14}$ His marriage to both princesses was to strengthen the devotion of people of Cirebon and Batang districts to the kingdom. From his marriage to Ratu Kulon, a son named Pangeran Alit was born to him and Ratu Wetan gave a birth to another son, named Raden Mas Sayidin. After Sultan Agung passed away, Raden Mas Sayidin killed Pangeran Alit and he enthroned himself as king of Mataram Islam entitled Amangkurat I. Amangkurat I also practiced polygamy and the reason seemed only for the sake of his pleasure. For example, he murdered a person who had been working in his palace as puppet player for long time named Dalang Panjang Mas, in order to get his wife, Ratu Mas Malang. Amangkurat I had fought with his own son, Raden Rahmat, who had a love affair with a girl who would be taken as wife by Amangkurat I, named Rara Oyi. Finally, Amangkurat I asked his son to kill Rara Oyi, so that neither one of them would marry her.

\footnotetext{
${ }^{12}$ http://id.wikipedia.org/wiki/Kerajaan_Galuh. Retrieved on $23^{\text {rd }}$ September 2011

${ }^{13} \mathrm{http}: / /$ mcfeet.wordpress.com/ Retrieved on $23^{\text {rd }}$ September 2011

14 http://www.bingkaindonesia.com/tokoh/19-sultan-agung-adi-prabu-hanyakrakusuma.html. Retrieved on $23^{\text {rd }}$ September 2011
} 
From the above facts, it could be seen that polygamy had already existed in Indonesia since the first millennium. In fact, polygamy was not practiced only by royal families but also by common people. This practice is continued from generation to generation; moreover, it gets ideological umbrella from many local philosophies which put women in lower position than men. Indonesians, especially Javanese people, believe in the concept that women are helper (konco wingking, literally it means friend-behind) of men because men are the leader of the family. ${ }^{15}$ Hence, mentally and financially women have the mindset to always depend on men. This non-independent attitude of women brings to the acceptance of whatever their husbands do, including polygamy. Besides that, marriage law regulated by government which allows polygamy under certain circumstances is also becoming another factor for the continuation of polygamy.

Marriage is regulated by Indonesian government in the Act $1 / 1974 .^{16}$ The general principle of marriage is a psychological and physical relationship between a female and a male as husband and wife for the purpose of forming a harmonious and happy family. ${ }^{17}$ Based on this rule, it is clear that the general principle of marriage regulated by government is monogamy and that is what is mentioned in the article number 3 subsection 1. However, there is a possibility for a man to have more wives because in the following subsection of the same article of the above regulation says that "man is allowed to marry to more than a woman if there is agreement between parties involved in it". ${ }^{18}$ The next article states that the marriage to more than one wife is allowed if the wife cannot do her duty (physically and mentally), get sick that cannot be cured or unfertile. ${ }^{19}$ Hence, if a wife is in the one of three aforementioned conditions, a husband can marry another woman as his new wife. With the above regulations, a married man by getting the consent from his wife and showing that he is able to give material, psychological and physical

15 http://esterlianawati.wordpress.com/2008/04/09/perempuan-jawa-konco-wingking-atau-sigaraning-nyawa/. Retrieved on $9^{\text {th }}$ October 2011.

${ }_{16}$ Undang-Undang Perkawinan (UUP) No.1 Tahun 1974. Marriage Law 1974. http://hukum.unsrat.ac.id/uu/uu_1_74.htm. Retrieved 11th October 2011.

17 The Act 1/1974, I, 1.

${ }^{18}$ The Act 1/1974, I, 1, (1). It might be because of philosophical view that woman is just like earth so that it cannot have many suns (husbands) at the same time, while husband as a sun, he is possible to have many planets at the same time. James Campbell. History and Philosophy of Marriage or Polygamy and Monogamy. Salt Lake City: Jos. Hyrum Parry and Co. 1885, p. 217

19 The Act 1/1974, I, 4 (1) 
needs to more than one wife will be granted permission to practice polygamy. ${ }^{20}$ The marriage law also mentions that if in the case a husband loses the contact with the wife within two years, he can marry to another woman without the consent and agreement from the missing-wife. ${ }^{21}$ However, in this marriage regulation, it is not clearly mentioned about the limitation of having wife. Due to influence of Islamic teaching, people are in the assumption that a man can have four wives at the same time.

What can be seen from the above regulation is a gender bias. According to these rules, in marriage life women are just considered as the agent of producing children, and therefore, if they fail to fulfill this duty as the consequence, polygamy must be accepted by them. Because of this reason, some Indonesian women and human right activists are demanding the government to amend the marriage law by abolishing the permission to practice polygamy for whatever the reason might be. ${ }^{22}$ However, because of the influence of the religious view of Islam as major religion, this demand has not been fulfilled by the government yet because polygamy is allowed in Islam.

Although Islamic teaching allows Muslims to marry to more than one wife, many Muslims, as the major citizens and in which their teachings have the direct influences to the permission of doing polygamy, are also debating it. Based on the teaching as depicted in the Surah An-Nisa, ${ }^{23}$ some Muslims say that having maximum four wives with the promise to deal justly to all wives, psychologically and psychically, is allowed. Supporters of polygamy say that it is the best way to reduce adultery and to help women of getting better life. ${ }^{24}$ They also say that statistically, women are more than men in numbers and definitely they will get difficulties in

${ }^{20}$ The Act 1/1974, I, 5, (1-2)

${ }^{22}$ http://www.lbh-apik.or.id/amandemen_UUP-usulan.htm. Retrieved $23^{\text {rd }}$ September 2011.

${ }^{23}$ And if you fear that you shall not be able to deal justly with the orphan-girls then marry (other) women of your choice, two or three, of four; but if you fear that you shall not be able to deal justly (with them), then only one or (the slaves) that your right hands possess. That is nearer to prevent you from perform doing injustice. An-Nissa,3.

24 http://www.menegpp.go.id/index.php?option=com content\&view=article\&id=105:poligami-tanggapan-ataskeputusan-mahkamah-konstitusi-\&catid=49:artikel-gender\&Itemid=116 (Official website of the Ministry of Woman Affair of Indonesia). This view is held by some people since the ancient time evidenced by the statement that "The experience of every age and of every community has proved that many men cannot and will not content themselves with one woman. There must be polygamy, or else there must be prostitution, and prostitution is wickedness, and wickedness is degradation". James Campbell. History and Philosophy of Marriage or Polygamy and Monogamy. Salt Lake City: Jos. Hyrum Parry ad Co. 1885, P. 209 
finding husband. ${ }^{25}$ In supporting polygamy, a polygamous man named Puspo Wardoyo, the owner of restaurant "Wong Solo" in Central Java is promoting the "polygamy award". ${ }^{26}$ This award is given to a man who is practicing successful polygamy. After reading the Hadiths, however, some Muslims come to the different opinion, saying that polygamy cannot be practiced. In the Hadiths there is a story when Ali bin Thalib, son in law of the Prophet Muhammad who marries to the Prophet's daughter named Fatimah, is asking Prophet's permission to marry to another woman and the Prophet does not allow it because it will hurt Fatimah. ${ }^{27}$ This is evidence that polygamy should not be practiced. Explaining why the prophet Muhammad has nine wives, this group says that the Prophet was doing polygamy because of social situation at that time where many widows need his help. Hence, his polygamous marriage was out of his compassion toward widows. In rejecting polygamy this group concludes that polygamy gives psychological pressure to woman. Though a man is having vast religious knowledges and good economic income, finally he still has problems with the wives due to psychological reasons. A.A. Gymnastiar, a famous Muslim preacher who divorced his first wife recently was a real example of it. ${ }^{28}$

\section{Marriage and Polygamy: A Buddhist View}

Speaking about marriage life, Buddhists as Indonesian citizens are also under the marriage law regulated by the government. Buddhist men can marry to more than one wife and therefore, Buddhist women are in the situation where they might have co-wife at any time. Usually, Buddhist men who are doing polygamy are married to the second wife based on Islamic custom. So, what they did is changing their religious status in the identity card and then conducts the second or third marriage in Islamic way. It is because in Islam there is "nikah siri" (informal Muslim marriage), a marriage which is legal according to Islamic law without being registered to

\footnotetext{
${ }^{25}$ But, this second reason is wrong because based on the recent census of Indonesian citizens shows that in general males citizen are 119.630.913 and females citizens are 118.010.413. Sex comparison in Indonesia in 2010 is 101,4. So, in every 1000 women there are $1014 \mathrm{men}$. http://dds.bps.go.id/download_file/IP_Oktober_2011.pdf . Retrieved on $11^{\text {th }}$ October 2011.

${ }^{26}$ http://polygamyagenda.com/awards32104.htm. Retrieved on 23 ${ }^{\text {rd }}$ September 2011. Cf; GATRA, Nomor 23 Beredar Senin 21 April 2003] (http://arsip.gatra.com/2003-04-21/versi_cetak.php?id=27357).

${ }^{27}$ Shahih Bukhari, Hadits No.4829.

28 http://www.republika.co.id/berita/nasional/umum/11/06/21/ln4f4j-hakim-kabulkan-permohonan-aa-gym-resmicerai-dengan-teh-ninih. Retrieved $23^{\text {rd }}$ September 2012
} 
the government. ${ }^{29}$ This kind of marriage just needs some people as witnesses, the permission of village authority, consent from parents and authorized by the Muslim cleric. Government usually is silent seeing this kind of marriage as it is allowed in major religion. Even though, nikah siri becomes debatable recently because the children of this kind of marriage will find difficulty to obtain the birth certificate and the wives are uncertain about their economic welfare.

The possibility of practicing polygamy for Buddhist men seems acceptable from the Buddhist view because there is no explicit rule in the Tipitaka which prohibits polygamy. And also, as it can be seen from Buddhist texts, there are many Buddha's disciples who are practicing polygamy such as King Pasenadi of Kosala ${ }^{30}$ and King Bimbisara. King Bimbisāra's chief queen was Kosaladevī ${ }^{-31}$ and the other wives are Khemā, ${ }^{32}$ the courtesan Padumavat ${ }^{-33}$ and also Ambapāli. ${ }^{34}$ Based on these facts, the question is "did the Buddha agree with the practice of polygamy? If the Buddha did not agree, why did not the Buddha teach them to lead a monogamous marriage?" These questions must be answered from the socio-historical background. First, it should be noted that they already have many wives before meeting the Buddha. King Bimbisāra who is five years younger than the Buddha ${ }^{35}$ must be getting married before the Ascetic Gotama attained enlightenment. Hence, it was impossible for the Buddha to tell them suddenly that having many wives was not good and therefore they should divorce their wives and juts live with one wife. It might create new problems, i.e., the welfare of the wives who were divorced. Second, it must be kept in mind that Buddhism is religion which considers marriage as secular; therefore, it is not regulated clearly in the Tipitaka. Not like Islam ${ }^{36}$ or

\footnotetext{
${ }^{29}$ It is also called as "nikah gantung” Kamus Besar Bahasa Indonesia. Jakarta: Balai Pustaka, 2001, p. 1003.

30 According to the Piyajātika Sutta, his chief queen is Queen Mallika and there another wife named Queen Vāsabhā (M.N. II, 108 ff). The Kaṇnakatthala Sutta (M. N. II, 125) mentions two others wives of King Pasenadi who were sisters named Somā and Sakulā.

31 bimbisārarañ̃̃o dhītaram vedehim nāma kosaladevim . Jāt.A. II, 403.

32 She finally enters the order and become the foremost among women disciples in great insight (mahāpaññānam). A.N. I, 25

33 Abhayamātutherīgāthāvaṇnanāa. ThigA. 38.

34 Rājā hi bimbisāro tarunakāle ambapāliyā rūpasampattim sutvā sañjātābhilāso katipayamanussaparivāro añ̃ātakavesena vesālim gantvā ekarattim tāya saṃvāsaṃ kappesi. ThagA.I, 155

${ }^{35}$ G.P. Malalasekera. Dictionary of Pāli Proper Names. London: Routledge and Keagan Paul. 1974, p. 285
} 
Abrahamic religions ${ }^{37}$ that teach that marriage is a duty, ${ }^{38}$ in Buddhist perspective getting married is a choice of individual. Marriage is neither prohibited nor recommended. Buddhists have freedom to choose whether they will marry or not because it is not a sin to be unmarried.

What is the real nature of marriage from Buddhist perspective? The Agaññā Sutta of the Dīgha Nikāya ${ }^{39}$ might give some clues for this question. In this sutta, it is elucidated that due to lust, male and female get attracted to each other and they end in sexual relationship. ${ }^{40}$ When the sexual relationship happens everywhere, people consider it as taboo and therefore those people who engage in sexual relationship are banned from the society. However, the sexual relationship is still remaining in the society. In due course of time, people start to build houses to conceal their sexual relationship. ${ }^{41}$ Gradually, people who live in the same house for long time have commitment to live together. This is the pioneer of marriage. What can be seen from this historical analysis is that, marriage has great possibility to be affected by lust. However, it does not mean that Buddhism totally sees the marriage as merely legalization of conjugal relationship. In the Mahāvacchagotta Sutta of the Majjhima Nikāya the Buddha teaches that the life as householders can also be directed for attaining Nibbanna. ${ }^{42}$ It is important principle that should be understood because the enlightenment is not monopoly for clergy but also possible to be gained by the householders. As can be witnessed in Buddhist texts, ${ }^{43}$ there are many householders who attain the fruits of purification such as Anāgāmī Ugga ${ }^{44}$ and Anāgāmī Hatthaka Alavaka. ${ }^{45}$ Visākhā ${ }^{46}$ and Aṇathapiṇdika ${ }^{47}$ as two chiefs lay female and male supporters of the Buddha who are stream winner can also be taken as another example.

\footnotetext{
${ }^{36}$ AN-Nissa 4, 3. (there is command to every human to have married (fankihu)

${ }^{37}$ And God blessed them, and God said unto them, Be fruitful, and multiply, and replenish the earth, and subdue it : and have dominion over the fish of the sea, and over the fowl of the air, and over every living thing that moveth upon the earth. Genesis II, 28

${ }^{38}$ Due to the idea that marriage is a duty, there is an argument says that unmarried women are wasting their sweetness in the open air. James Campbell. History and Philosophy of Marriage or Polygamy and Monogamy. Salt Lake City: Jos. Hyrum Parry ad Co. 1885, P. 63

${ }^{39}$ D.N. III, 82, ff

${ }^{40}$ D.N. III, 89

${ }^{41}$ Maurice Walshe. The Long Discourses of the Buddha. Boston: Wisdom Publications, 1995, p. 412

${ }^{42}$ M. N. I , 491

${ }^{43}$ A.N.I, 26

${ }^{44}$ who is the best of those who gave agreeable gifts (manāpadāyakānam)

45 who is foremost among those who gather a following by means of the four bases of sympathy (catūhi vatthühi parisam sanganhantānam)

46 A.N. IV,348
} 
How can householders attain the stages of purification? It is by balancing the development of the mundane and spiritual life. Practicing the Noble Eightfold Path i.e., having good conduct (sīla), developing concentration of mind (samādhi) and realizing insight (pañ்̃ $\bar{a})$ must be the way of life. These three should be practiced simultaneously. To start the training of good conduct, the Buddha has advised lay people to observe precepts whether five precepts $\left(\right.$ pañcasīla) ${ }^{48}$ in daily life or eight precepts (atthasīla) on the Uposatha day. ${ }^{49}$ On the uposatha day, Buddhist householders are advised to practice celibate life. ${ }^{50}$ Even according to the Suttanipāta, householders may practice celibate life daily. If in the case one finds difficulty to practice celibate life, one should not have relationship with others' wife. ${ }^{51}$ The Gihi Sutta of the Anguttara Nikāya says that it is not only by avoiding relationship with others' wives but one must also be glad with their own wife. ${ }^{52}$ What is the significance of the training to practice celibate life? The purpose of this training is to train the householders to reduce the sensual indulgence (kämacchanda) which is one of the five hindrances. ${ }^{53}$ It is because, as far as $k \bar{a} m a c c h a n d a$ is in existence the concentration (samādhi) will not be gained and the insight (pañ்̃a) will not be realized. ${ }^{54}$ As the result, people are entangled in saṃsäric cycle and far away from Nibbāna. Based on this teaching, what can be summed up is that, the polygamous life will have much risks and difficulties in training the celibate life and reducing the attachment of sensual pleasures. Not only increasing the risk to be trapped in sensual indulgence, polygamy also creates more familial obstacle (kula palibodha) in doing meditation. ${ }^{55}$ The best example is the explanation in the Piyajātika Sutta in which the dear and near ones in the families are the

\footnotetext{
${ }^{47}$ S.N. I, 212

${ }^{48}$ Pānātipātā pațivirato ca hoti, adinnādānā paṭivirato ca hoti, kāmesumicchācārā paṭivirato ca hoti, musāuāāa pațivirato ca hoti, surāmerayamajjappamādaț̣̂ānā pațivirato. Pañcasīla Sutta. S. N. IV, 245 cf: D. N. III, 235 ; S. N. 1V, 245, A. N. I, 211,

49 A.N. I. 214.

${ }^{50}$ A.N. I, 211.

${ }^{51}$ Abrahmacariyam parivajjayeyya, añgārakāsum jalitaṃva viññū; Asambhuṇanto pana brahmacariyaṃ, parassa dāram na atikkameyya. Sn. 398

52 'Sehi dārehi santuțtho, paradārañca ārame. A. III. 213.

${ }^{53}$ Five hindrances are: Kāmacchanda, byāpāda, thinamiddha, uddhaccakukkucca, and vicikiccha. D. N. II, 300.

${ }^{54}$ pañca nīvarạ̣e pahāya cetaso upakkilese paññāya dubbalīkaraṇe. Uttiya Sutta. A.N. V, 193 or Avaraṇā Sutta. A.N. III. 63

55 Puna caparam, mahārāja, ākāso alaggo asatto appatițthito apalibuddho, evameva kho, mahārāja, yoginā yogāvacarena kule gaṇe lābhe āvāse palibodhe paccaye sabbakilesesu ca sabbattha alaggena bhavitabbam, anāsattena appatițthitena apalibuddhena bhavitabbaṃ. Miln. 388. Cf: Vims 91.
} 
source of worries and will bring to the despair and lamentation if separation happens. ${ }^{56}$ Hence, it can be said that polygamy gives more possibility to prolong the life in the samsāric journey.

Seeing the above facts, how should Buddhist women deal with polygamy issue in maintaining her family life? Firstly and foremost, women must empower themselves with the ability to manage the family as can be seen in the Sigalovāda Sutta. ${ }^{57}$ Secondly, it is by building good communication with the husband so that both wife and husband will be able to possess

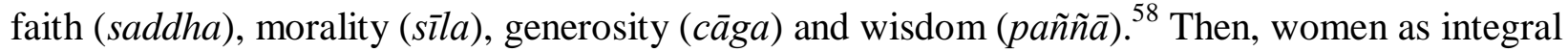
part of the family as far as possible should bring the religious atmosphere to the family to make it close to the Dhamma. It is by encouraging all family members to practice the good conduct, cultivating the mind in order to develop wisdom. Visākhā is the best example for lay female disciple who has succeeded to bring her family to the Dhammic way. That is why, as far as the texts are concerned, there is no report of polygamy practiced by her husband, Paññāvadhana. Due to greatness of Visākhā as wife, daughter-in-law and inspiratory of Dhamma, she is known as "Migāramāta", a mother of Migāra, her father in law. It is only by having a good Dhammic understanding, a family will get real happiness where husband and wife will not think how to marry another woman or man but, how to support each other to get rid from samsāric cycle.

\footnotetext{
${ }^{56}$ M.N. II, 105, ff.

${ }^{57}$ D.N. III, 180

${ }^{58}$ samasaddhā samasīlā samacāgā samapaññā. A.N. II, 61
} 
References:

1. Bhikkhu Bodhi. The Connected Discourses of the Buddha. Vol. II. Boston: Wisdom Publication, 2000

2. Bhikkhu Ñānamoli. The Path of Purification. Fifth Edition. Kandy: Buddhist Publication Society, 1999

3. Bhikkhu Nyāṇamoli and Bhikkhu Bodhi. Middle Length Discourses of the Buddha. Kandy: BPS, 1995

4. Bhikkhu Pesala. The Debate of King Milinda. Delhi: Motilal Banarsidass Publishers, 1991

5. Dr. Muhammad Taqī Ud-Dīn AL Hilali and Dr Muhammad Muhsin Khan. The Noble Qur'an. Madinah: K.S.A., 1949

6. Ernest Klein. Etymological English Dictionary. London: Elsevier Publishing Company, 1966

7. F.L. Woodward. Paramattha-Dīpanī. London: Luzac and Company. 1971

8. G.P. Malalasekera. Dictionary of Pāli Proper Names. London: Routledge and Keagan Paul. 1974

9. J.A.B. Van Buitenen. Mahābhārata. Chicago: University of Chicago Press, 1975

10. James Campbell. History and Philosophy of Marriage or Polygamy and Monogamy. Salt Lake City: Jos. Hyrum Parry ad Co., 1885

11. Kamus Besar Bahasa Indonesia. Jakarta: Balai Pustaka, 2001

12. Maurice Walshe. The Long Discourses of the Buddha. Boston: Wisdom Publications, 1995

13. Oxford Advanced Learner's Dictionary $5^{\text {th }}$ Edition. Oxford: Oxford University Press, 1995

14. The Act 1/1974 based on http://hukum.unsrat.ac.id/uu/uu_1_74.htm.

15. The Holy Bible. Bengalore: Theological Publication in India, 1973. 
